\title{
KINERJA SAHAM PT AQUA GOLDEN MISSISSIPPI TBK. SETELAH PEMBATALAN GO PRIVATE DAN ESTIMASI HARGA SAHAM AQUA TAHUN 2010
}

\author{
Indah Wandita Putri ${ }^{1}$; Mohamad Heykal ${ }^{2}$ \\ 1,2 Jurusan Akuntansi, Universitas Bina Nusantara \\ Jln. K.H. Syahdan No. 9, Palmerah, Jakarta Barat 11480 \\ m_heykal@binus.ac.id, mohammadheykal@binus.edu
}

\begin{abstract}
PT Aqua Golden Mississippi is a company that plans to go private, but until today have not obtained approval from the shareholders. Failure may be caused from several things: the company offer price is too small, no quorum, shares held is still profitable for shareholders, and other factors. The existence of the company's plan to go private would affect the performance of the company stock. Stock performance can be analyzed with - average rate of profit, the level of risk, and sensitivity to the stock exchange. The method used in the calculation of stock performance in this paper is the GMR, STDEV, CAPM, and DDM for the calculation of estimated stock price. Through the conducted analysis, investors / shareholders are encouraged to pay attention to the news and information related to go private to be conducted by the company, stock performance, and perform estimate calculations. This is to find out what the right decision for private investors.
\end{abstract}

Keywords: go private, share, performance, action, corporation

\begin{abstract}
ABSTRAK
PT AQUA Golden Mississippi adalah salah satu perusahaan yang merencanakan untuk melakukan go private hingga saat ini, namun tidak disetujui oleh para pemegang saham. Gagalnya perseroan melakukan go private dapat disebabkan oleh beberapa hal, yaitu harga yang ditawarkan perseroan terlalu kecil, tidak tercapainya kuorum, saham yang dimiliki masih menguntungkan bagi pemegang saham, dan faktor-faktor lainnya. Adanya rencana perseroan untuk melakukan go private tentunya berpengaruh terhadap kinerja saham perseroan tersebut. Kinerja saham dapat dianalisis dengan rata-rata tingkat laba, tingkat risiko, dan sensitifitas saham terhadap bursa. Metode yang dipakai dalam perhitungan kinerja saham dalam artikel ini adalah GMR, STDEV, CAPM, dan DDM untuk perhitungan estimasi harga saham. Melalui analisis yang dilakukan, investor/ pemegang saham dianjurkan untuk memperhatikan berita-berita dan informasi yang berkaitan dengan go private yang akan dilakukan oleh perseroan, kinerja saham, dan melakukan perhitungan estimasi. Hal ini bertujuan untuk mengetahui keputusan apa yang tepat untuk dilakukan investor.
\end{abstract}

Kata kunci: go private, kinerja, saham, perusahaan, aksi 


\section{PENDAHULUAN}

Dalam mengembangkan usahanya perusahaan dapat melakukan berbagai cara, salah satunya adalah ekspansi. Untuk memenuhi kebutuhan ekspansi diperlukan sumber dana yang tidak sedikit. Pasar modal merupakan salah satu sumber pendanaan, selain sumber-sumber pendanaan yang terdahulu, yaitu perbankan. Selain dana yang dihimpun lebih besar, pendanaan dari pasar modal tidak perlu menyediakan agunan seperti halnya perbankan. Salah satu alternatif yang dapat dilakukan dalam mencari tambahan dana itu adalah dengan pihak lain yang mau ikut menanam modalnya pada perusahaan. Salah satunya dengan melakukan Penawaran umum saham (go public) ini sering dikenal pula dengan istilah initial public offering (IPO). IPO adalah penawaran perdana saham kepada publik.

Beberapa keuntungan yang diperoleh dengan melakukan go public tidak menutup kemungkinan bagi perusahaan tersebut untuk melakukan go private. Pengertian go private adalah perusahaan yang semula sahamnya dimiliki oleh publik (perusahaan terbuka), kemudian berubah kembali menjadi perusahaan tertutup yang sahamnya hanya dimiliki oleh segelintir pemegang saham saja. Salah satu alasan suatu perusahaan melakukan go private adalah karena merasa terbebani oleh biaya-biaya yang harus dikeluarkan dan kewajiban-kewajiban sebagai perusahaan terbuka. Adapun biaya dan kewajiban tersebut antara lain adalah tingginya biaya konsultan hukum dan akuntansi, biaya penyelenggaraan RUPS, kewajiban memenuhi peraturan pasar modal, kesibukan melayani analisis surat berharga, dan lain-lainnya.

Selain itu, juga terdapat beberapa alasan lainnya perusahaan melakukan go private adalah tidak terpenuhinya maksud dan tujuan utama perusahaan pada saat menjadi perusahaan go public. Seharusnya dengan menjadi perusahaan publik, perusahaan mendapatkan kemudahan untuk akses di dalam pasar modal daripada perusahaan tertutup. AQUA merupakan produsen air mineral dalam kemasan (AMDK) yang terbesar di Indonesia. Hal ini adalah salah satu kelebihan yang dimiliki AQUA sehingga sahamnya diminati oleh masyarakat. Namun, hal tersebut tidak menutup kemungkinan bahwa AQUA tetap menjadi perusahaan terbuka. Rencana go private telah dilakukan 3 kali, yaitu pada tahun 2001, 2005, dan 2009. Pada tahun 2001, PT AQUA gagal mendapat persetujuan dari pemegang saham minoritas karena saham yang ditawarkan terlalu rendah sebesar Rp 35.000 per lembar saham. Kemudian, pada tahun 2005 terjadi Rapat Umum Pemegang Saham Luar Biasa (RPUSLB) sebanyak 3 kali. Pada rapat pertama dan kedua tidak terjadi kuorum, namun pada rapat ketiga terjadi kuorum, tetapi rencana go private ditolak oleh sebagian besar pemegang saham.

Pada tahun 2009 go private tetap ditolak kembali oleh pemegang saham minoritas. Hal ini mengakibatkan adanya pergerakan kinerja saham tersebut baik setelah pembatalan go private maupun pelaksanaan go private selanjutnya. Hal itulah yang menjadi alasan dari dibuatnya penelitian Analisis Kinerja Saham PT AQUA Golden Mississippi Tbk. setelah Pembatalan Go Private dan Estimasi Harga Saham Aqua Tahun 2010". Adapun ruang lingkup dari penelitian ini adalah apakah terdapat berita fundamental yang relevan berkaitan dengan pembatalan go private PT AQUA Golden Mississippi Tbk. pada tahun 2001, 2005, dan 2009 serta bagaimanakah kinerja saham PT AQUA Golden Mississippi Tbk dengan kinerja bursa saham selama periode 2005 - 2009?, Berapakah estimasi harga saham PT AQUA Golden Mississippi Tbk. bila go private tetap tidak terlaksana?.

\section{METODE PENELITIAN}

\section{Pasar Modal}

Pasar modal (capital market) didefinisikan sebagai perdagangan instrumen keuangan (sekuritas) jangka panjang, baik dalam bentuk modal sendiri (stocks) maupun hutang (bonds), baik 
yang diterbitkan oleh pemerintah (public authorities) maupun oleh perusahaan swasta (private sectors). Usman et al. (1997:11) menyatakan bahwa pasar modal merupakan konsep yang lebih sempit dari pasar keuangan (financial market). Dalam financial market, diperdagangkan semua hutang dan modal sendiri, baik jangka pendek maupun jangka panjang, baik yang bersifat negotiable maupun yang non negotiable. Sedangkan Darmadji et al. (2006:1) menyatakan bahwa pasar modal merupakan pasar untuk berbagai instrumen keuangan jangka panjang yang bisa diperjual-belikan, baik dalam bentuk utang maupun modal sendiri. Menurut Undang-Undang No.8 tahun 1995, pasar modal diartikan sebagai kegiatan yang bersangkutan dengan penawaran umum dan perdagangan efek, perusahaan publik yang berkaitan dengan efek yang diterbitkannya serta lembaga dan profesi yang berkaitan dengan efek. Pasar modal memiliki 2 fungsi penting dalam perekonomian suatu negara, yaitu sebagai alternatif sumber pendanaan bagi perusahaan dan sarana investasi bagi publik. Dana yang diperoleh perusahaan dengan menawarkan sahamnya dapat digunakan untuk ekspansi bisnis, restrukturisasi dan lain-lain. Bagi masyarakat yang memiliki kelebihan dana, dapat menginvetasikan dana yang dimilikinya di pasar modal sesuai dengan tingkat pengembalian yang diinginkan dan tingkat risiko yang berani ditanggung.

\section{Saham}

Darmadji et al. (2006:6) menyatakan bahwa saham (stock atau share) dapat didefinisikan sebagai tanda penyertaan atau pemilikan seseorang atau badan dalam suatu perusahaan atau perseroan terbatas. Saham berwujud selembar kertas yang menerangkan bahwa pemilik kertas adalah pemilik perusahaan yang menerbitkan surat berharga tersebut. Porsi kepemilikan ditentukan oleh seberapa besar penyertaan yang ditanamkan di perusahaan tersebut. Menurut Siamat (2005:507), saham atau stocks adalah surat bukti atau tanda kepemilikan bagian modal pada suatu perseroan terbatas. Dalam transaksi jual beli di Bursa Efek, saham atau sering pula disebut dengan shares merupakan instrumen yang paling dominan diperdagangkan. Saham terdiri dari beberapa jenis, di antaranya adalah bila dilihat dari segi kemampuan dalam Hak Tagih atau Klaim, maka saham terbagi atas (1) Saham biasa (common stocks), yaitu merupakan saham yang menempatkan pemiliknya paling yunior terhadap pembagian deviden, dan hak atas harta kekayaan perusahaan apabila perusahaan tersebut dilikuidasi; (2) Saham preferen (preffered stocks), merupakan saham yang memiliki karakteristik gabungan antara obligasi dan saham biasa karena bisa menghasilkan pendapatan tetap, tetapi juga bisa mendatangkan hasil seperti yang dikehendaki investor.

Ditinjau dari cara peralihan saham, maka saham terbagi atas (1) Saham atas unjuk (bearer stocks), artinya pada saham terbentuk tidak tertulis nama pemiliknya, agar mudah dipindahtangankan dari satu investor ke investor lainnya. Secara hukum siapa yang memegang saham tersebut, maka dialah yang diakui sebagai pemiliknya dan berhak untuk ikut hadir dalam RUPS; (2) Saham atas nama (registered stocks), merupakan saham yang ditulis dengan jelas siapa nama pemiliknya, cara peralihannya harus melalui prosedur tertentu. Ditinjau dari kinerja perdagangan, maka saham terbagi atas (1) Blue-Chip Stocks, yaitu saham biasa dari suatu perusahaan yang memiliki reputasi tinggi, sebagai leader di industri sejenis, memiliki pendapatan yang stabil dan konsisten dalam membayar deviden; (2) Income Stocks, yaitu saham dari suatu emiten yang memiliki kemampuan membayar deviden lebih tinggi dari rata-rata deviden yang dibayarkan pada tahun sebelumnya; (3) Growth Stocks (well-known), yaitu saham-saham dari emiten yang memiliki pertumbuhan pendapatan yang tinggi, sebagai leader di industri sejenis yang mempunyai reputasi tinggi. Selain itu, terdapat growth stocks (lesser-known), yaitu saham dari emiten yang tidak sebagai leader dalam industri namun memiliki ciri growth stock; (4) Speculative Stocks, yaitu saham suatu perusahaan yang tidak bisa secara konsisten memperoleh penghasilan dari tahun ke tahun, akan tetapi mempunyai kemungkinan penghasilan yang tinggi di masa mendatang, meskipun belum pasti; (5) Counter Cyclical Stocks, yaitu saham yang tidak terpengaruh oleh kondisi ekonomi makro maupun situasi bisnis secara umum". 


\section{Pendekatan Analisis Saham}

Analisis saham yang dimaksud di sini adalah mengumpulkan data, mengorganisasikan dan mengolahnya dengan kerangka kerja yang logis, kemudian menggunakan hasilnya yang berupa informasi untuk mengukur tingkat kinerja suatu saham. Kinerja suatu saham adalah penilaian atas suatu saham berdasarkan perhitungan yang dilakukan untuk menentukan tingkat laba (return), dan tingkat risiko (risk) yang terkandung dalam suatu saham. Secara umum terdapat 3 faktor yang dapat dipakai dalam menganalisis kinerja saham, yaitu rata-rata tingkat laba, tingkat risiko, dan sensifitas saham terhadap bursa.

Rata-rata tingkat laba merupakan analisis tingkat laba yang dilakukan untuk menentukan berapa laba yang akan diperoleh oleh investor atas kepemilikan suatu saham. Tingkat laba dapat berupa realized return yang sudah terjadi atau expected return yang belum terjadi, tetapi yang diharapkan akan terjadi di masa mendatang. Dalam menentukan daily return diperlukan spot price saat ini dan spot price sebelumnya. Daily return dapat ditentukan dengan menggunakan rumus aplikasi software excel sebagai berikut:

\section{Daily return $=\mathbf{L N}\left(\right.$ number $_{1} /$ number $\left._{0}\right)$}

Di mana:

number $_{1}=$ spot price saat ini

number $_{0}=$ spot price sebelumnya

Untuk menghitung rata - rata dari tingkat laba dalam satu periode dapat dihitung menggunakan Geometric Mean Return (GMR). GMR adalah metode yang digunakan untuk mengukur susunan tarif dari pertumbuhan (rate of growth) sepanjang waktu. GMR terkadang digunakan dalam investasi dan keuangan untuk menggambarkan tarif pertumbuhan yang tetap dari dana investasi sepanjang beberapa periode yang lampau. GMR ditentukan sebagai akar yang paling akhir dari produk yang dihasilkan dari perkembangan relative return. GMR dirumuskan sebagai berikut:

$$
G M R=\sqrt[n]{\left(1+R_{1}\right) x\left(1+R_{2}\right) \times \ldots x\left(1+R_{n}\right)}-1
$$

Di mana:

$\mathrm{R}=$ tingkat laba saham

$\mathrm{n}=$ jumlah data yang digunakan

Tingkat risiko. Analisis tingkat risiko, yaitu analisis yang dilakukan untuk menentukan berapa risiko yang akan ditanggung oleh investor atas kepemilikan suatu saham. Metode yang banyak dilakukan untuk mengukur tingkat risiko adalah standar deviasi. Menurut Ridwan et al. (2002:53), standar deviasi merupakan indikator statistik yang paling umum dari risiko suatu aktiva yang mengukur sebaran sekitar nilai yang diharapkan. Standar deviasi digunakan untuk mengukur penyimpangan dari setiap pengamatan dan merupakan alat pengukuran yang dapat dipercaya karena meliputi semua sampel yang dikumpulkan. Pada umumnya, semakin tinggi standar deviasi, semakin besar risikonya. Rumus yang biasa digunakan untuk standar deviasi, di mana kemungkinan terjadinya diketahui dan probabilitasnya sama adalah sebagai berikut:

$$
\sigma=\frac{\sum \mathbf{f}(\mathbf{X}-\mu)^{2}}{\mathrm{~N}}
$$

Sensitifitas saham terhadap bursa. Sensitifitas saham terhadap bursa dapat diperoleh dengan menggunakan beta risk $(\beta)$. Beta risk $(\beta)$ atau yang disebut juga sebagai systematic risk, adalah tingkat 
sensitifitas suatu saham terhadap kejadian yang berlangsung di bursa, dihubungkan dengan indeks saham (misal IHSG atau LQ45). Semakin besar beta risk, semakin sensitif harga saham tersebut bila terjadi perubahan sentimen bursa (semakin riskan), dan beta risk tidak dapat dikurangi dengan diversifikasi asset. Beta risk dapat dihitung dari regresi linier antara tingkat laba saham (Ri) dan tingkat laba pasar (Rm). Beta risk dapat dirumuskan sebagai berikut:

$$
\mathbf{R}_{\mathrm{i}}=\alpha_{\mathrm{i}}+\beta_{\mathrm{i}} \mathbf{R}_{\mathrm{M}}+\varepsilon
$$

Dalam perhitungan beta risk, terdapat salah satu data yang dibutuhkan, yaitu harga suatu asset. Untuk menentukan harga suatu aset, diperlukan metode Capital Assets Pricing Model (CAPM). Suad Husnan (2001:159) mengungkapkan bahwa CAPM merupakan model untuk menentukan harga suatu aset. Model ini mendasarkan diri pada kondisi equilibrium. Dalam keadaan equilibrium, tingkat keuntungan yang diisyaratkan oleh pemodal suatu saham akan dipengaruhi oleh risiko saham pasar tersebut. CAPM memberikan landasan intelektual bagi beberapa praktek sekarang ini dalam industri investasi. Salah satu indikatornya adalah beberapa investor atau lembaga keuangan mencoba menghitung dan menaksir beta dari saham-saham yang dipergunakan di suatu bursa. CAPM dapat dirumuskan sebagai berikut:

$$
\mathbf{C A P M}=\mathbf{R}_{\mathbf{f}}+\boldsymbol{\beta}\left(\mathbf{R}_{\mathrm{m}}-\mathbf{R}_{\mathbf{f}}\right)
$$

Di mana:

$\mathrm{R}_{\mathrm{f}}=$ bunga bank Indonesia

$\beta=$ beta risk

$\mathrm{R}_{\mathrm{m}}=$ tingkat laba pasar

Selain ketiga hal tersebut, terdapat beberapa hal yang harus diperhatikan dalam rangka analisis saham, yaitu Devidend Discounted Model dan juga bunga bank Indonesia. Devidend Discounted Model merupakan metode untuk mengetahui harga suatu saham pada periode berikutnya atau yang dikenal dengan estimasi harga saham. Dalam meng-estimasi harga saham digunakan pertumbuhan yang konstan. Untuk menentukannya digunakan rumus sebagai berikut:

$$
P_{0}=\frac{d(1+g)}{k-g}
$$

Di mana:

$\mathrm{d}=$ dividend

$\mathrm{g}=$ growth

$\mathrm{k}=$ cost of equity (stock)

Sementara BI Rate adalah suku bunga kebijakan yang mencerminkan sikap atau kebijakan moneter yang ditetapkan oleh Bank Indonesia dan diumumkan kepada public.

\section{Go Public}

Darmadji et al. (2006:73) menyatakan bahwa penawaran umum atau yang sering juga disebut dengan go public adalah kegiatan penawaran saham atau efek lainnya yang dilakukan oleh Emiten (perusahaan yang akan go public) untuk menjual saham atau efek kepada masyarakat berdasarkan tata cara yang diatur oleh UU Pasar Modal dan Peraturan Pelaksanaan. Adapun manfaat penawaran umum saham antara lain (1) Dapat memperoleh dana yang relatif besar dan diterima sekaligus; (2) Biaya go public relatif murah; (3) Proses relatif mudah; (4) Pembagian deviden berdasarkan keuntungan; (5) Penyertaan masyarakat biasanya tidak masuk dalam manajemen; (6) Perusahaan dituntut lebih terbuka 
sehingga hal ini dapat memacu perusahaan untuk meningkatkan profesionalisme; (7) Memberikan kesempatan kepada masyarakat untuk turut serta memiliki saham perusahaan sehingga dapat mengurangi kesenjangan sosial; (8) Emiten akan lebih dikenal oleh masyarakat (go public merupakan media promosi) secara gratis; dan (9) Memberikan kesempatan bagi koperasi dan karyawan perusahaan untuk membeli saham".

\section{Go Private}

Tindakan go private merupakan aksi korporasi yang merupakan kebalikan dari tindakan go public. Pada tindakan go public, suatu perusahaan menjual sahamnya kepada publik sehingga menjadi perusahaan terbuka. Sebaliknya, pada tindakan go private perusahaan terbuka berubah statusnya menjadi perusahaan tertutup. Menurut Widjaja et al. (2009:32), go private artinya perusahaan yang sahamnya semula dimiliki oleh publik (perusahaan terbuka), berubah kembali menjadi perusahaan tertutup yang dimiliki oleh segelintir pemegang saham saja. Adapun beberapa alasan yang dilakukan oleh perusahaan untuk melakukan go private adalah (1) Perusahaan merasa lebih mendapat keuntungan jika go private; (2) Biaya menjadi perusahaan publik mahal karena antara lain adanya kewajiban untuk menyampaikan laporan keuangan kuartal dan tahunan; (3) Kondisi kinerja dan keuangan perusahaan yang kuat sehingga tidak perlu lagi memperoleh dana dari masyarakat; (4) Perusahaan tidak perlu lagi membagi hasil keuntungan dan beberapa persyaratan lain yang berhubungan dengan pemilikan saham; (5) Perusahaan menganggap tidak ada prospek menarik bagi mereka untuk tetap terdaftar di Bursa karena kinerja usaha terus memburuk; (6) Adanya kesepakatankesepakatan tertentu yang dilakukan pemegang saham mayoritas dengan investor baru, yang mensyaratkan perusahaan untuk go private; (7) Competitive intelligence, di mana kewajiban disclosure information berpotensi menguntungkan para pesaingnya dan ini tidak terjadi di perusahaan tertutup; (8) Controlling function, dengan go private dapat dihindari kemungkinan pihak luar (outsider) untuk membeli saham pengendali.

Keputusan untuk melakukan go private tentunya memiliki beberapa konsekuensi (Widjaja et al., 2009:35-37), di antaranya adalah (1) Terhadap emiten.Tujuan utama emiten untuk bergerak di pasar modal adalah untuk mencari dana yang lebih cepat dan efektif dibandingkan dengan memperoleh pinjaman dari bank. Dengan dilakukannya go private, emiten tidak lagi memperoleh manfaat-manfaat ekonomi yang didapat di Bursa. Namun di sisi lain, emiten tidak perlu lagi melaksanakan prinsip keterbukaan terhadap masyarakat; (2) Terhadap investor. Investor yang bermain di pasar modal tentu sangat berharap dapat memperoleh capital gain yang tinggi dari saham yang dimilikinya sebagai bentuk penyertaan modal yang telah ditanamkan di perusahaan. Dengan memiliki saham, investor berharap dapat dengan cepat memperoleh keuntungan karena apabila sewaktu-waktu membutuhkan dana, mereka dapat dengan mudah menjual saham yang dimiliki. Dengan adanya pelaksanaan go private oleh emiten, investor tentu tidak dapat lagi memiliki saham dari perusahaan yang bersangkutan dan mendapatkan keuntungan atas saham tersebut; (3) Terhadap efek. Efek dari perusahaan yang melakukan go private tentu tidak dapat lagi diperdagangkan di bursa maupun di luar bursa karena status perusahaan yang sudah menjadi perusahaan tertutup.

Jenis data yang digunakan dalam penelitian ini merupakan data sekunder, dengan menggunakan metode kuantitatif. Sumber data yang digunakan dalam penelitian ini adalah data harga saham PT AQUA Golden Mississippi Tbk. yang diambil dari Bursa Efek Indonesia (BEI) periode 2005 hingga 2009, data harga bursa saham (IHSG) periode 2005 - 2009 yang diambil dari Bursa Efek Indonesia (BEI), bunga Bank Indonesia periode 2005 - 2009 yang diambil dari situs www.bi.go.id, situs www.finance.yahoo.com, laporan keuangan PT AQUA Golden Mississippi Tbk yang diambil dari www.reuters.com, dan bahan penunjang lainnya.

Dalam penulisan ini, data yang diperoleh penulis dari beberapa sumber diolah kembali oleh penulis dengan menggunakan berbagai metode perhitungan sesuai dengan analisis yang penulis 
peroleh pada landasan teori pada bab sebelumnya, yaitu (1) Untuk mengukur rata-rata tingkat laba digunakan metode LN, GMR dan AAR; (2) Untuk mengukur tingkat risiko digunakan standar deviasi; (3) Untuk mengukur sensitifitas saham terhadap bursa digunakan beta risk dan CAPM; (4) Dalam perhitungan GMR, LN, AAR, standar deviasi, beta risk, dan CAPM (k) digunakan perangkat lunak (software) Microsoft Office Excel 2003. Berikut adalah perhitungan metode tersebut: LN $\left(\right.$ number $_{1} /$ number $\left._{0}\right) ;$ GMR $=\left(\right.$ multiplicative $^{\wedge}(1 /$ stock price $\left.)\right)-1 ;$ Standar deviasi $=\operatorname{STDEV}\left(\right.$ number $_{1}$, $[$ number 2$], \ldots$ ); Beta risk = slope (known_y's, known_x's), di mana Known_y's = Ri (harga saham AQUA) dan Known_x's $=R$ m (IHSG); CAPM $=R_{\mathrm{f}}+\beta\left(\mathrm{R}_{\mathrm{m}}-\mathrm{R}_{\mathrm{f}}\right)$, di mana $\mathrm{R}_{\mathrm{f}}=$ bunga Bank Indonesia, $\beta=$ beta risk, $\mathrm{R}_{\mathrm{m}}=$ tingkat laba pasar (IDX); (5) Untuk menentukan estimasi harga saham digunakan metode perhitungan Devidend Discounted Model (DDM). Rumus DDM adalah sebagai berikut:

$$
P_{0}=\frac{d(1+g)}{k-g}
$$

Di mana :

$\mathrm{d}=$ dividend

$\mathrm{g}=$ growth

$\mathrm{k}=$ cost of equity (stock)

Pada analisis berita fundamental, peneliti menggunakan sumber-sumber berita yang akurat dan telah dipastikan kebenarannya karena berita yang peneliti peroleh adalah sumber berita yang telah diakui oleh masyarakat umum maupun kalangan lainnya. Berita tersebut sesuai dengan adanya kejadian pembatalan go private yang dialami oleh PT AQUA Golden Mississippi Tbk., yaitu terbagi menjadi 3 tahun, yaitu tahun 2001, 2005, dan 2009. Berdasarkan berita yang telah peneliti peroleh, artikel tersebut peneliti olah sehingga menjadi sebuah tabel yang berisi berita alasan mengenai terjadinya pembatalan go private, harga buy back saham AQUA, dan harga pasar saham tersebut pada saat terjadinya pembatalan go private.Pada analisis kinerja saham, data akan disajikan dalam bentuk tabel yang berisi data-data harga saham AQUA bulanan (penutupan harga), data IHSG, data bunga Bank Indonesia, perhitungan Rm (IHSG), Ri (saham AQUA), Rm+1, dan Multiplicative. Pada perhitungan estimasi harga saham, data akan disajikan dalam bentuk 2 tabel. Tabel pertama adalah tabel untuk perhitungan devidend growth, tabel tersebut berisi deviden saham AQUA semenjak tahun 2005 hingga 2009, perhitngan Rm, Rm+1, dan multiplicative. Kemudian, pada tabel kedua berisi data harga saham AQUA, data IHSG, perhitungan Rm (IHSG), Ri (saham AQUA), Rm+1, multiplicative, dan bunga Bank Indonesia periode 2005 hingga 2009. Selanjutnya, berdasarkan 2 tabel tersebut, akan disajikan kembali dalam bentuk 2 tabel yang berisi hasil dari perhitungan Devidend Discounted Model (DDM) yang berfungsi untuk menentukan harga saham kedepan dan tabel yang berisi harga saham saat ini sehingga 2 tabel tersebut dapat menjadi perbandingan dan dapat diambil pendapat mengenai perhitungan estimasi harga saham tahun 2010.

\section{HASIL DAN PEMBAHASAN}

Menurut Widjaja et al. (2009:80-89), prosedur yang harus dilakukan oleh perseroan untuk melakukan go private adalah persetujuan RUPS independen, penawaran tender, pasca-penawaran tender, dan delisting. Pada penelitian ini, pembahasan mengenai analisis berita fundamental yang relevan dengan pembatalan go private PT AQUA Golden Mississippi Tbk. terjadi pada tahun 2001, 2005, dan 2009. Faktor utama pembatalan go private yang dialami PT AQUA Golden Mississippi Tbk. adalah pada saat tidak disetujuinya penawaran tender yang dilakukan perseroan tersebut. 
Tabel 1 Bagan Mengenai Penolakan Penawaran Tender yang Terjadi tahun 2001, 2005, dan 2009 oleh Investor Publik

\begin{tabular}{|c|c|c|c|}
\hline Tahun & Berita \& Sumber & Harga Buy Back & Harga Pasar \\
\hline 2001 & $\begin{array}{l}\text { perseroan gagal mendapat persetujuan pemegang saham } \\
\text { minoritas, karena pemegang saham minoritas yang } \\
\text { jumlahnya sekitar } 9 \% \text { menolak harga yang ditawarkan } \\
\text { perusahaan sebesar } 35000 \text { rupiah per saham. Pemegang } \\
\text { saham minoritas menilai harga yang diberikan terlalu } \\
\text { rendah karena sama dengan harga pasar perusahaan pada } \\
\text { tanggal } 21 \text { Desember } 2001 \text {. } \\
\text { Sumber :koranjakarta.com }\end{array}$ & $\begin{array}{l}\text { Rp } 35.000 \\
\text { per lembar } \\
(\text { Des } 2001)\end{array}$ & $\operatorname{Rp} 35.000$ \\
\hline 2005 & $\begin{array}{l}\text { pemegang saham kembali menolak rencana go private } \\
\text { perseroan, Di mana suara yang mendukung go private } \\
\text { tidak memenuhi kuorum, padahal perseroan sudah } \\
\text { menawarkan harga pembelian kembali saham sebesar } \\
100.000 \text { ribu per lembar berdasarkan pertumbuhan volume } \\
13 \% \text { per tahun, pertumbuhan net income } 15 \% \text { per tahun } \\
\text { selama } 5 \text { tahun mendatang. Asumsi harga penawaran } \\
\text { berdasarkan pertumbuhan industri menurut Willy Sidharta } \\
\text { (Dirut AQUA). } \\
\text { Sumber : detikfinance.com }\end{array}$ & $\begin{array}{l}\text { Rp } 100.000 \\
\text { per lembar } \\
\text { (Des 2005) }\end{array}$ & $\begin{array}{l}\text { Rp 50.000- } \\
\operatorname{Rp} 63.000\end{array}$ \\
\hline 2009 & $\begin{array}{l}\text { perseroan telah menawarkan harga pembelian kembali } \\
\text { saham sebesar } 450.000 \text { ribu per lembar namun perseroan } \\
\text { belum mendapatkan izin dari BAPEPAM untuk } \\
\text { melaksanakan rencana go private. Respon pemegang } \\
\text { saham publik sangat baik karena perseoan menawarkan } \\
\text { harga Rp } 450.000 \text { per lembar saham Di mana harga } \\
\text { tersebut } 124,89 \% \text { di atas harga wajar tim penilaian } \\
\text { independen aqua, atau senilai Rp } 200.095 \text { per lembar } \\
\text { saham, juga harga tersebut } 83 \% \text { lebih tinggi dari harga } \\
\text { pasar selama } 2 \text { tahun terakhir. Beberapa pemilik saham } \\
\text { minoritas memiliki indikasi dengan permintaan harga } \\
\text { sampai } 1 \text { juta saham per lembar. } \\
\text { Sumber : okezone.com }\end{array}$ & $\begin{array}{l}\text { Rp } 450.000 \\
\text { per lembar } \\
\text { (Des 2009) }\end{array}$ & Rp 244.800 \\
\hline
\end{tabular}

Sementara itu, berkaitan dengan kinerja saham dari PT Aqua Golden Missisippi Tbk., berikut adalah perhitungan hasil kinerja saham pada periode 2005-2009 .

Tabel 2 Kinerja Saham dan Kinerja Bursa Tahun 2005

\begin{tabular}{llrrrrrr}
\hline \multicolumn{1}{c}{ Periode } & Stock Price & IHSG & Rm & \multicolumn{1}{c}{ Ri } & \multicolumn{1}{c}{ Rm+1 } & Multiplicative & BI Rate \\
\hline Januari & $46,500.00$ & $1,045.44$ & & & & & \\
Februari & $48,000.00$ & $1,073.83$ & $2.68 \%$ & $3.17 \%$ & $102.68 \%$ & & \\
Maret & $46,200.00$ & $1,080.17$ & $0.59 \%$ & $-3.82 \%$ & $100.59 \%$ & $103.28 \%$ & \\
April & $50,500.00$ & $1,029.61$ & $-4.79 \%$ & $8.90 \%$ & $95.21 \%$ & $98.33 \%$ & \\
Mei & $51,000.00$ & $1,088.17$ & $5.53 \%$ & $0.99 \%$ & $105.53 \%$ & $103.77 \%$ & \\
Juni & $49,000.00$ & $1,122.38$ & $3.10 \%$ & $-4.00 \%$ & $103.10 \%$ & $106.98 \%$ & \\
Juli & $55,000.00$ & $1,182.30$ & $5.20 \%$ & $11.55 \%$ & $105.20 \%$ & $112.55 \%$ & $8.50 \%$ \\
Agustus & $48,000.00$ & $1,050.09$ & $-11.86 \%$ & $-13.61 \%$ & $88.14 \%$ & $99.20 \%$ & $8.75 \%$ \\
September & $50,000.00$ & $1,079.28$ & $2.74 \%$ & $4.08 \%$ & $102.74 \%$ & $101.92 \%$ & $10.00 \%$ \\
Oktober & $50,000.00$ & $1,066.22$ & $-1.22 \%$ & $0.00 \%$ & $98.78 \%$ & $100.68 \%$ & $11.00 \%$ \\
November & $50,000.00$ & $1,096.64$ & $2.81 \%$ & $0.00 \%$ & $102.81 \%$ & $103.51 \%$ & $12.25 \%$ \\
Desember & $63,000.00$ & $1,162.64$ & $5.84 \%$ & $23.11 \%$ & $105.84 \%$ & $109.56 \%$ & $12.75 \%$ \\
\hline
\end{tabular}

Sumber: diolah oleh peneliti 
Tabel 3 Tingkat Risiko dan Keuntungan Tahun 2005

\begin{tabular}{lcc}
\hline & Risk & Return \\
\hline AQUA & $9.52 \%$ & $0.83 \%$ \\
IDX & $5.28 \%$ & $0.97 \%$ \\
BI Rate & $1.77 \%$ & $10.54 \%$ \\
\hline \multicolumn{3}{c}{ Sumber: diolah oleh peneliti }
\end{tabular}

Pada tahun 2005, saham AQUA memiliki tingkat risiko sebesar 9,52\% dan tingkat pengembalian sebesar 0,83\%. Pada IDX, memiliki tingkat risiko sebesar 5,28\% dan tingkat pengembalian sebesar $0,97 \%$. Sedangkan pada BI Rate tingkat risiko sebesar $1,77 \%$ dan tingkat pengembalian sebesar $10,54 \%$.

Tabel 3 Kinerja Perdagangan Saham dan Bursa Tahun 2006

\begin{tabular}{lrlrrrrr}
\hline \multicolumn{1}{c}{ Periode } & Stock Price & IHSG & \multicolumn{1}{c}{ Rm } & \multicolumn{1}{c}{ Ri } & Rm+1 & Multiplicative & BI Rate \\
\hline Januari & $104,400.00$ & $1,232.32$ & & & & & $12.75 \%$ \\
Februari & $70,000.00$ & $1,230.66$ & $-0.13 \%$ & $-39.97 \%$ & $99.87 \%$ & & $12.75 \%$ \\
Maret & $71,000.00$ & $1,322.97$ & $7.23 \%$ & $1.42 \%$ & $107.23 \%$ & $107.09 \%$ & $12.75 \%$ \\
April & $76,000.00$ & $1,464.41$ & $10.16 \%$ & $6.81 \%$ & $110.16 \%$ & $117.97 \%$ & $12.75 \%$ \\
Mei & $72,000.00$ & $1,330.00$ & $-9.63 \%$ & $-5.41 \%$ & $90.37 \%$ & $106.61 \%$ & $12.50 \%$ \\
Juni & $94,000.00$ & $1,310.26$ & $-1.50 \%$ & $26.66 \%$ & $98.50 \%$ & $105.01 \%$ & $12.50 \%$ \\
Juli & $94,330.00$ & $1,351.65$ & $3.11 \%$ & $0.35 \%$ & $103.11 \%$ & $108.28 \%$ & $12.25 \%$ \\
Agustus & $93,500.00$ & $1,431.26$ & $5.72 \%$ & $0.00 \%$ & $105.72 \%$ & $114.48 \%$ & $11.75 \%$ \\
September & $92,000.00$ & $1,534.61$ & $6.97 \%$ & $-1.62 \%$ & $106.97 \%$ & $122.46 \%$ & $11.25 \%$ \\
Oktober & $81,000.00$ & $1,582.63$ & $3.08 \%$ & $-12.73 \%$ & $103.08 \%$ & $126.23 \%$ & $10.75 \%$ \\
November & $99,000.00$ & $1,718.96$ & $8.26 \%$ & $20.07 \%$ & $108.26 \%$ & $136.66 \%$ & $10.25 \%$ \\
Desember & $98,000.00$ & $1,805.52$ & $4.91 \%$ & $-1.02 \%$ & $104.91 \%$ & $143.38 \%$ & $9.75 \%$ \\
\hline
\end{tabular}

Sumber : diolah oleh peneliti

Tabel 4 Tingkat Risiko dan Keuntungan Tahun 2006

\begin{tabular}{lcr}
\hline & Risk & Return \\
\hline AQUA & $17.18 \%$ & $3.33 \%$ \\
IDX & $5.57 \%$ & $3.47 \%$ \\
BI Rate & $1.08 \%$ & $11.83 \%$ \\
\hline \multicolumn{3}{c}{ Sumber: diolah oleh peneliti }
\end{tabular}

Pada tahun 2006, saham AQUA memiliki tingkat risiko sebesar $17,18 \%$ dan tingkat pengembalian sebesar 3,33\%. Pada IDX, memiliki tingkat risiko sebesar 5,57\% dan tingkat pengembalian sebesar 3,47\%. Sedangkan pada BI Rate tingkat risiko sebesar $1,08 \%$ dan tingkat pengembalian sebesar $11,83 \%$. 
Tabel 5 Kinerja Perdagangan Saham dan Bursa Tahun 2007

\begin{tabular}{lccrrrrr}
\hline \multicolumn{1}{c}{ Periode } & Stock Price & IHSG & Rm & Ri & Rm+1 & Multiplicative & BI Rate \\
\hline Januari & $130,000.00$ & $1,757.26$ & & & & & $9.50 \%$ \\
Februari & $129,500.00$ & $1,740.97$ & $-0.93 \%$ & $-0.39 \%$ & $99.07 \%$ & & $9.25 \%$ \\
Maret & $129,000.00$ & $1,830.92$ & $5.04 \%$ & $-0.39 \%$ & $105.04 \%$ & $104.06 \%$ & $9.00 \%$ \\
April & $129,500.00$ & $1,999.17$ & $8.79 \%$ & $0.39 \%$ & $108.79 \%$ & $113.21 \%$ & $9.00 \%$ \\
Mei & $129,500.00$ & $2,084.32$ & $4.17 \%$ & $0.00 \%$ & $104.17 \%$ & $117.93 \%$ & $8.75 \%$ \\
Juni & $110,000.00$ & $2,139.28$ & $2.60 \%$ & $-16.32 \%$ & $102.60 \%$ & $121.00 \%$ & $8.50 \%$ \\
Juli & 130.130 .00 & $2,348.67$ & $9.34 \%$ & $16.81 \%$ & $109.34 \%$ & $132.30 \%$ & $8.25 \%$ \\
Agustus & $129,500.00$ & $2,194.34$ & $-6.80 \%$ & $0.00 \%$ & $93.20 \%$ & $123.31 \%$ & $8.25 \%$ \\
September & $129,500.00$ & $2,359.21$ & $7.24 \%$ & $0.00 \%$ & $107.24 \%$ & $132.24 \%$ & $8.25 \%$ \\
Oktober & $102,000.00$ & $2,643.49$ & $11.38 \%$ & $-23.87 \%$ & $111.38 \%$ & $147.28 \%$ & $8.25 \%$ \\
November & $125,000.00$ & $2,688.33$ & $1.68 \%$ & $20.33 \%$ & $101.68 \%$ & $149.76 \%$ & $8.25 \%$ \\
Desember & $130,000.00$ & $2,745.83$ & $2.12 \%$ & $3.92 \%$ & $102.12 \%$ & $152.93 \%$ & $8.00 \%$ \\
\hline
\end{tabular}

Sumber : diolah oleh peneliti

Tabel 6 Tingkat Risiko dan Keuntungan Tahun 2007

\begin{tabular}{lrr}
\hline & \multicolumn{1}{c}{ Risk } & \multicolumn{1}{c}{ Return } \\
\hline AQUA & $12.44 \%$ & $3.94 \%$ \\
IDX & $5.19 \%$ & $4.06 \%$ \\
BI Rate & $0.48 \%$ & $8.60 \%$ \\
\hline
\end{tabular}

Sumber: diolah oleh peneliti

Pada tahun 2007, saham AQUA memiliki tingkat risiko sebesar 12,44\% dan tingkat pengembalian sebesar 3,94\%. Pada IDX, memiliki tingkat risiko sebesar 5,19\% dan tingkat pengembalian sebesar $4,06 \%$. Sedangkan pada BI Rate tingkat risiko sebesar $0,48 \%$ dan tingkat pengembalian sebesar $8,60 \%$.

Tabel 7 Kinerja Perdagangan Saham dan Bursa Tahun 2008

\begin{tabular}{lcrrrrrr}
\hline \multicolumn{1}{c}{ Periode } & Stock Price & IHSG & Rm & Ri & Rm+1 & Multiplicative & BI Rate \\
\hline Januari & $104,000.00$ & $2,627.25$ & & & & & $8.00 \%$ \\
Februari & $104,000.00$ & $2,721.94$ & $3.54 \%$ & $0.00 \%$ & $103.54 \%$ & & $8.00 \%$ \\
Maret & $100,000.00$ & $2,447.30$ & $-10.64 \%$ & $-3.92 \%$ & $89.36 \%$ & $92.53 \%$ & $8.00 \%$ \\
April & $125,000.00$ & $2,304.52$ & $-6.01 \%$ & $22.31 \%$ & $93.99 \%$ & $86.97 \%$ & $8.00 \%$ \\
Mei & $130,000.00$ & $2,444.35$ & $5.89 \%$ & $3.92 \%$ & $105.89 \%$ & $92.09 \%$ & $8.25 \%$ \\
Juni & $110,000.00$ & $2,349.10$ & $-3.97 \%$ & $-16.71 \%$ & $96.03 \%$ & $88.43 \%$ & $8.50 \%$ \\
Juli & $128,000.00$ & $2,304.51$ & $-1.92 \%$ & $15.15 \%$ & $98.08 \%$ & $86.73 \%$ & $8.75 \%$ \\
Agustus & $130,000.00$ & $2,165.94$ & $-6.20 \%$ & $2.33 \%$ & $93.80 \%$ & $81.36 \%$ & $9.00 \%$ \\
September & $130,000.00$ & $1,832.51$ & $-16.72 \%$ & $0.00 \%$ & $83.28 \%$ & $67.76 \%$ & $9.25 \%$ \\
Oktober & $125,500.00$ & $1,256.70$ & $-37.72 \%$ & $-3.52 \%$ & $62.28 \%$ & $42.20 \%$ & $9.50 \%$ \\
November & $126,500.00$ & $1,241.54$ & $-1.21 \%$ & $0.79 \%$ & $98.79 \%$ & $41.69 \%$ & $9.50 \%$ \\
Desember & $126,500.00$ & $1,355.41$ & $8.78 \%$ & $0.00 \%$ & $108.78 \%$ & $45.34 \%$ & $9.25 \%$ \\
\hline
\end{tabular}

Sumber : diolah oleh peneliti 
Tabel 8 Tingkat Risiko dan Keuntungan Tahun 2008

\begin{tabular}{lcc}
\hline & Risk & Return \\
\hline AQUA & $10.09 \%$ & $-6.94 \%$ \\
IDX & $12.79 \%$ & $-6.02 \%$ \\
BI Rate & $0.62 \%$ & $8.67 \%$ \\
\hline \multicolumn{3}{c}{ Sumber : diolah oleh peneliti } \\
\hline
\end{tabular}

Pada tahun 2008, saham AQUA memiliki tingkat risiko sebesar $10,09 \%$ dan tingkat pengembalian sebesar -6,94\%. Pada IDX, memiliki tingkat risiko sebesar 12,79\% dan tingkat pengembalian sebesar $-6,02 \%$. Sedangkan pada BI Rate, tingkat risiko sebesar $0,62 \%$ dan tingkat pengembalian sebesar $8,67 \%$.

Tabel 9 Kinerja Perdagangan Saham dan Bursa Tahun 2009

\begin{tabular}{lcrrrrrr}
\hline \multicolumn{1}{c}{ Periode } & Stock Price & \multicolumn{1}{c}{ IHSG } & \multicolumn{1}{c}{$\mathrm{Rm}$} & \multicolumn{1}{c}{$\mathrm{Ri}$} & \multicolumn{1}{c}{$\mathrm{Rm}+1$} & Multiplicative & BI Rate \\
\hline Januari & $135,000.00$ & $1,332.67$ & & & & & $8.75 \%$ \\
Februari & $135,000.00$ & $1,285.48$ & $-3.61 \%$ & $0.00 \%$ & $96.39 \%$ & & $8.25 \%$ \\
Maret & $125,000.00$ & $1,434.07$ & $10.94 \%$ & $-7.70 \%$ & $110.94 \%$ & $106.94 \%$ & $7.75 \%$ \\
April & $155,000.00$ & $1,722.77$ & $18.34 \%$ & $21.51 \%$ & $118.34 \%$ & $126.55 \%$ & $7.50 \%$ \\
Mei & $155,000.00$ & $1,916.83$ & $10.67 \%$ & $0.00 \%$ & $110.67 \%$ & $140.06 \%$ & $7.25 \%$ \\
Juni & $244,800.00$ & $2,026.78$ & $5.58 \%$ & $45.70 \%$ & $105.58 \%$ & $147.87 \%$ & $7.00 \%$ \\
Juli & $246,000.00$ & $2,323.24$ & $13.65 \%$ & $0.49 \%$ & $113.65 \%$ & $168.06 \%$ & $6.75 \%$ \\
Agustus & $244,800.00$ & $2,341.54$ & $0.78 \%$ & $0.00 \%$ & $100.78 \%$ & $169.38 \%$ & $6.50 \%$ \\
September & $244,800.00$ & $2,467.59$ & $5.24 \%$ & $0.00 \%$ & $105.24 \%$ & $178.26 \%$ & $6.50 \%$ \\
Oktober & $244,800.00$ & $2,367.70$ & $-4.13 \%$ & $0.00 \%$ & $95.87 \%$ & $170.89 \%$ & $6.50 \%$ \\
November & $244,800.00$ & $2,415.84$ & $2.01 \%$ & $0.00 \%$ & $102.01 \%$ & $174.33 \%$ & $6.50 \%$ \\
Desember & $244,800.00$ & $2,534.36$ & $4.79 \%$ & $0.00 \%$ & $104.79 \%$ & $182.68 \%$ & $6.50 \%$ \\
\hline
\end{tabular}

Sumber : diolah oleh peneliti

Tabel 10 Tingkat Risiko dan Keuntungan Tahun 2009

\begin{tabular}{lcc} 
& Risk & Return \\
\hline AQUA & $15.13 \%$ & $5.63 \%$ \\
IDX & $7.05 \%$ & $5.84 \%$ \\
BI Rate & $0.77 \%$ & $7.15 \%$ \\
\hline \multicolumn{3}{c}{ Sumber : diolah oleh peneliti }
\end{tabular}

Pada tahun 2009, saham AQUA memiliki tingkat risiko sebesar $15,13 \%$ dan tingkat pengembalian sebesar 5,63\%. Pada IDX, memiliki tingkat risiko sebesar 7,05\% dan tingkat pengembalian sebesar 5,84\%. Sedangkan pada BI Rate tingkat risiko sebesar 0,77\% dan tingkat pengembalian sebesar $7,15 \%$.

\section{Estimasi Harga Saham Tahun 2010}

Berdasarkan rumus dan tata cara perhitungan yang telah disajikan sebelumnya, berikut adalah hasil perhitungan devidend growth menggunakan metode AAR dan GMR. 
Tabel 11 Perhitungan Dividend Growth

\begin{tabular}{ccrrr}
\hline \multicolumn{1}{c}{ Tahun } & Deviden & Rm & Rm+1 & Multiplicative \\
\hline 2005 & 1,180 & & & \\
2006 & 830 & $-30 \%$ & $70 \%$ & \\
2007 & 630 & $-24 \%$ & $76 \%$ & $53.39 \%$ \\
2008 & 1,000 & $59 \%$ & $159 \%$ & $84.75 \%$ \\
2009 & 1,200 & $20 \%$ & $120 \%$ & $101.69 \%$ \\
\hline AAR & $6.24 \%$ & & \\
GMR & $0.42 \%$ & & \\
\hline \multicolumn{5}{c}{ Sumber : diolah oleh peneliti }
\end{tabular}

Berdasarkan data yang telah diolah di atas, maka dividend growth yang digunakan untuk perhitungan estimasi selanjutnya menggunakan metode aritmatika, karena dengan metode tersebut hasilnya akan lebih mendekati harga pasar saat ini, yaitu Rp 244.800 dibandingkan dengan metode geometrika. Berikut adalah perhitungan estimasi harga saham pada tahun 2010. Berdasarkan rumus Devidend Discounted Model (DDM) yang telah disebutkan di atas, maka hasilnya sebagai berikut.

Tabel 12 Perhitungan dividend discounted mode

\begin{tabular}{|c|c|c|c|c|c|c|c|}
\hline Tahun & Stock Price & IHSG & $\mathbf{R m}$ & $\mathbf{R i}$ & $\mathrm{Rm}+1$ & $\begin{array}{c}\text { Multiplicat } \\
\text { ive }\end{array}$ & BI Rate \\
\hline 2005 & $50,600.00$ & $1,089.73$ & & & & & $10.54 \%$ \\
\hline 2006 & $87,033.33$ & $1,442.94$ & $28.08 \%$ & $54.23 \%$ & $128.08 \%$ & & $11.83 \%$ \\
\hline 2007 & $125,250.00$ & $2,210.98$ & $42.68 \%$ & $36.40 \%$ & $142.68 \%$ & $182.73 \%$ & $8.60 \%$ \\
\hline 2008 & $119,875.00$ & $2,087.59$ & $-5.74 \%$ & $-4.39 \%$ & $94.26 \%$ & $172.24 \%$ & $8.67 \%$ \\
\hline 2009 & $201,550.00$ & $2,014.07$ & $-3.59 \%$ & $51.96 \%$ & $96.41 \%$ & $166.06 \%$ & $7.15 \%$ \\
\hline $\mathrm{n}$ & 4 & & $\mathrm{Rm}$ & $13.52 \%$ & & $\mathrm{~K}$ & $7.28 \%$ \\
\hline GMR & $0.42 \%$ & & Rf & $7.15 \%$ & & $\mathrm{G}$ & $6.24 \%$ \\
\hline AAR & $6.24 \%$ & & Beta(reuters) & $2.00 \%$ & & D & 1200 \\
\hline beta risk & $46.30 \%$ & & $\mathrm{k}$ & $7.28 \%$ & & Po & $123,277.04$ \\
\hline
\end{tabular}

Sumber: diolah oleh penulis berdasarkan data dari idx dan www.bi.go.id

Berdasarkan hasil perhitungan di atas, maka diketahui bahwa estimasi harga saham pada tahun 2010, dengan menggunakan pertumbuhan tetap (constant growth) sebesar Rp 1.200, maka hasil yang diperoleh adalah $\mathrm{Rp} 123.277,04$

Berdasarkan rangkaian penelitian tersebut, maka dapat dilihat bahwa kinerja saham PT AQUA Golden Mississippi Tbk. selama 5 tahun, yaitu tahun 2005 hingga 2009 menurut perhitungan yang di atas telah diketahui bahwa kinerja saham AQUA tidak lebih baik jika dibandingkan dengan kinerja bursa saham, dan jika dibandingkan dengan kinerja bunga Bank Indonesia, kinerja saham AQUA masih tidak lebih baik. Tetapi, jika hanya melihat dari perkembangan / pertumbuhan saham selama 5 tahun, maka kinerja saham AQUA menggambarkan uptrend yang terus-menerus setiap tahunnya. Begitu pun dengan pembayaran deviden yang teratur dibayar setiap bulan Juli, saham AQUA memiliki deviden yang cukup baik, walaupun pada tahun 2006 - 2007 devidend mulai mengalami penurunan sebesar Rp 630 - Rp 830 tetapi pada tahun 2008 -2009 devidend mulai mengalami kenaikan sebesar Rp 1.200 melebihi tahun 2005 yang hanya mencapai Rp 1.180 


\section{Perbandingan Estimasi Harga Saham Tahun 2010 dengan Harga Pasar Tahun 2009}

Tabel 13

Asumsi 4 Tahun Kedepan

\begin{tabular}{cr}
\hline K & $7.28 \%$ \\
G & $6.24 \%$ \\
D & 1200 \\
Po & $123,277.04$ \\
\hline
\end{tabular}

Tabel 14

Harga Pasar Tahun 2009

\begin{tabular}{lr}
\hline $\mathrm{k}$ & $7.28 \%$ \\
$\mathrm{~g}$ & $6.75 \%$ \\
$\mathrm{~d}$ & 1200 \\
$\mathrm{Po}$ & $244,800.00$ \\
\hline
\end{tabular}

Dari hasil perhitungan di atas, dapat terlihat harga saham tahun 2010 sebesar Rp 123.277,04, kemudian saat harga tersebut disamakan dengan harga akhir tahun 2009 sebesar Rp 244.800,00 terjadi selisih perbedaan pada growth sebesar $0,51 \%$ yang didapat dari selisih $6,75 \%-6,24 \%$. Perbedaan selisih growth sebesar $0,51 \%$ dapat terjadi karena adanya perbedaan antara permintaan atau hasil yang diharapkan oleh para investor dengan perhitungan nilai wajar. Perbedaan tersebut juga terjadi dikarenakan adanya proses go private yang pada akhirnya dimanfaatkan oleh para investor untuk mengambil keuntungan sebelum keputusan go private terjadi.

\section{Sensitifitas Saham}

Pada perhitungan sensitifitas saham yang telah dilakukan sebelumnya, dapat diambil kesimpulan bahwa sensitifitas saham yang terjadi pada tahun 2005 mencapai angka 0,42 hingga tahun 2007 mengalami kenaikkan yang terus-menerus hingga mencapai angka 10,45. Hal ini disebabkan oleh kegagalan go private yang terjadi pada tahun 2005 dikarenakan tidak tercapainya kuorum, yang pada saat itu harga yang ditawarkan oleh perseroan sebesar Rp 100.000 per lembar saham sedangkan harga pasar saat itu hanya berkisar antara Rp 50.000 - Rp 63.000 per lembar saham, sehingga semenjak saat itu saham AQUA riskan terhadap isu-isu, informasi, dan keputusan yang berhubungan dengan naik atau turunnya harga saham AQUA. Kemudian pada tahun 2008, sensitifitas saham mulai menurun hingga mencapai angka 6,80 dan mulai menurun kembali menjadi 6,56 pada tahun 2009 . Menurunnya sensitifitas saham pada tahun berikutnya dapat disebabkan oleh mulai kembali tenangnya isu-isu yang berkembang setelah terjadi kegagalan go private pada tahun 2005 yang lalu.

Hasil analisis yang dilakukan oleh penulis adalah setelah adanya pembatalan go private yang merupakan salah satu aksi korporasi yang dilakukan oleh perseroan, menunjukkan kinerja saham cukup baik / perform karena setelah pembatalan go private harga saham AQUA memiliki peningkatan yang terus-menerus membaik. Menurut Amir Hamzah (2002) setelah adanya salah satu aksi korporasi reverse stock split mempengaruhi harga saham menjadi tidak begitu baik / under perform. Sehingga penulis tidak sependapat dengan jurnal yang dilakukan oleh Amir Hamzah. Hal ini disebabkan aksi korporasi yang dilakukan oleh penulis, yaitu go private pada industri makanan dan minuman berbeda dengan jurnal yang dilakukan oleh Amir Hamzah yaitu aksi korporasi reverse stock split pada perbankan. Alasan penulis membandingkan hasil analisis penulis dengan jurnal yang dilakukan oleh Amir Hamzah adalah dari permasalahan yang dikemukakan terdapat persamaan, yaitu sama-sama merupakan aksi korporasi. Selain itu, sampai dengan saat ini penulis belum menemukan jurnal mengenai kinerja saham setelah pembatalan aksi korporasi go private. 


\section{SIMPULAN}

Berdasarkan analisis, perhitungan, dan perbandingan yang telah dilakukan sebelumnya, maka diperoleh beberapa kesimpulan. Pertama, berdasarkan pembatalan go private yang dialami oleh PT AQUA Golden Mississippi Tbk., dapat ditarik kesimpulan bahwa terdapat indikasi dari pihak investor minoritas untuk menahan saham yang dimiliki tersebut, karena saham tersebut masih memiliki kinerja yang cukup baik. Dilihat dari sisi pembagian deviden, perseroan teratur dalam pembagian deviden tersebut setiap bulan juli dan deviden yang diterima hampir selalu meningkat, walaupun pada tahun 2006 - 2007 sempat mengalami penurunan, tetapi tahun selanjutnya kembali meningkat hingga Rp 1.200 melebihi tahun 2005 yang hanya mencapai Rp 1.180. Kemudian, alasan AQUA melakukan go private lebih diakibatkan adanya keuntungan besar yang telah diterima oleh perseroan sebagai perusahaan terbuka selama ini. Sehingga keuntungan yang semakin besar ini diharapkan hanya diterima oleh perseroan saja, karena dengan adanya status perusahaan terbuka, perseroan harus tetap membagi deviden pada pemilik saham yang ada pada publik.

Kedua, kinerja saham AQUA setelah pembatalan go private yaitu semenjak tahun 2005 hingga tahun 2009 dapat dikatakan baik karena kinerja saham tersebut mengalami kenaikkan yang signifikan dari harga Rp 50.000 per lembar saham pada awal januari 2005, hingga kini mencapai Rp 244.800 per lembar saham. Namun, jika dibandingkan dengan kinerja bursa saham, kinerja saham AQUA tidak lebih baik dari segi tingkat pengembalian maupun tingkat risikonya. Demikian pula dengan bunga Bank Indonesia, kinerja saham AQUA tidak lebih baik.

Ketiga, berdasarkan perhitungan estimasi harga saham AQUA jika pelaksanaan go private tetap tidak terlaksana pada tahun 2010 dengan tingkat pertumbuhan yang konstan yaitu sebesar $\mathrm{Rp}$ 1.200 maka harga yang dihasilkan adalah $\mathrm{Rp} 123.277,04$ Jika harga tersebut disamakan dengan harga saham saat ini, yaitu sebesar Rp 244,800.00 maka terjadi perbedaan $0,51 \%$ pada tingkat pertumbuhan, yang sebelumnya hanya sebesar $6.24 \%$ menjadi $6.75 \%$. Perbedaan tersebut dapat terjadi karena dengan adanya proses go private pada perseroan ini, maka investor minoritas tetap menginginkan tingkat pengembalian yang tinggi sebelum go private tersebut dapat terlaksana, terbukti dengan harga saham yang meningkat hingga saat ini. Maka berdasarkan perhitungan sebelumnya keputusan yang dapat diambil adalah menjual saham tersebut jika deviden saham tidak melebihi Rp 1.200. Namun, jika devidennya melebihi Rp 1.200, maka keputusan yang diambil adalah tetap menahan saham tersebut, karena saham tersebut masih menguntungkan bagi investor.

Adapun sebagai saran dalam penelitian yang berguna bagi pembaca, investor, dan calon investor adalah sebagai berikut. Pertama, sebagai investor yang memiliki saham suatu perseroan hendaknya selalu mencari informasi dan berita-berita yang berhubungan dengan saham yang dimiliki. Kedua, adanya rencana aksi korporasi go private dapat mempengaruhi kinerja saham kedepannya, baik saham tersebut akan semakin memburuk ataupun terjadi peningkatan pengembalian yang terus membaik. Beberapa faktor yang dapat digunakan untuk menganalisis kinerja saham adalah rata-rata tingkat laba, tingkat risiko, dan sensitifitas saham. Hal ini dapat dimanfaatkan investor untuk menganalisis apakah saham tersebut masih memiliki tingkat keuntungan yang baik bagi investor. Ketiga, melakukan perhitungan estimasi pada saham tersebut untuk periode berikutnya atau beberapa periode kedepan untuk mengetahui apakah yang didapat apabila saham tersebut tetap dipertahankan atau jika saham tersebut dijual. Perhitungan estimasi ini dapat dibagi atau dikategorikan menjadi 3 jenis estimasi, yaitu estimasi no growth, constant growth, atau super normal growth. Hal ini dapat berfungsi menjadi salah satu pertimbangan bagi investor untuk menentukan apakah keputusan yang harus dilakukan dengan yaitu buy or sell. 


\section{DAFTAR PUSTAKA}

Darmadji, T. dan Fakhruddin, H.M. (2006). Pasar Modal Di Indonesia (Pendekatan Tanya Jawab) Edisi Pertama. PT Salemba Empat. Jakarta.

Republik Indonesia. Undang-undang RI Nomor 8 Tahun 1995 tentang Pasar Modal, Lembaran Negara Republik Indonesia Tahun 1995 Nomor 64. Sekretariat Negara. Jakarta.

Siamat, D., (2005), Manajemen Lembaga Keuangan Kebijakan Moneter dan Perbankan, Edisi Kelima, Jakarta: Lembaga Penerbit Fakultas Ekonomi Universitas Indonesia.

Usman, M, Singgih dan Syahrir (1997) Pengetahuan Dasar Pasar Modal. Institut Bankir Indonesia. Jakarta

Widjaja, G. dan Risnamanitis, W..(2009) Go Public dan Go Private di Indonesia. 2009. Seri Pengetahuan Pasar Modal. Jakarta: Kencana Prenada Media Group. 